
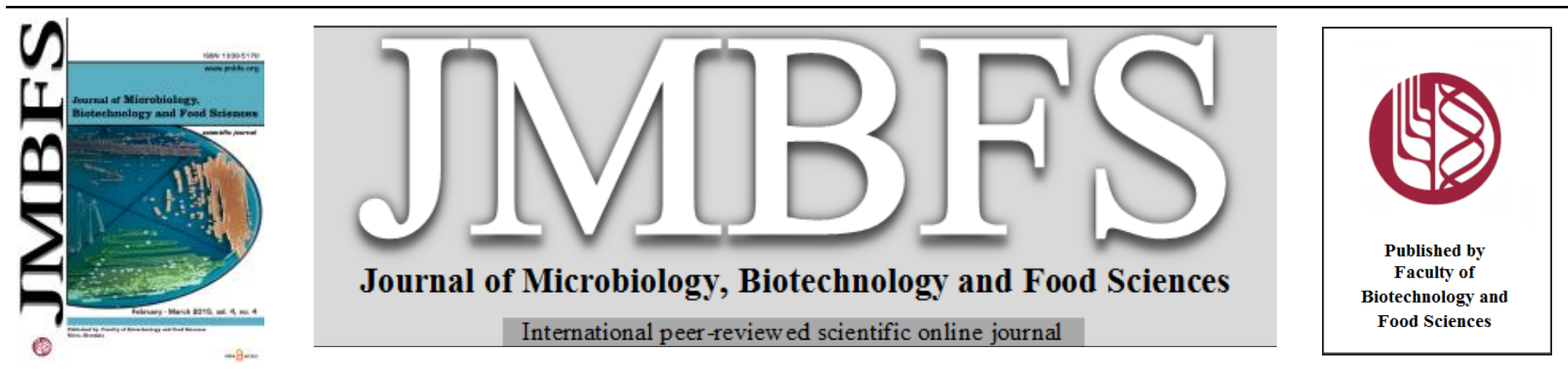

\title{
FUNCTIONAL MECHANISMS OF PROBIOTICS
}

\section{Bijender Kumar Bajaj ${ }^{1,2}$, Ingmar J.J. Claes $^{2}$ and Sarah Lebeer ${ }^{2}$}

\author{
Address(es): \\ ${ }^{1}$ School of Biotechnology, University of Jammu, Jammu- 180006 INDIA Phone +91-94191-02201; Fax: +91-191-2456534 \\ ${ }^{2}$ Department of Bioscience Engineering, University of Antwerp, Groenenborgerlaan 171, B-2020, Antwerp, Belgium.
}

*Corresponding author: bijenderbajaj@yahoo.com ; bajajbijenderk@gmail.com

doi: 10.15414/jmbfs.2015.4.4.321-327

\section{ARTICLE INFO}

Received 21. 8. 2014

Revised 2. 10. 2014

Accepted 5. 12. 2014

Published 1. 2. 2015

\section{Review}

OPEN $\partial_{\text {ACCESS }}$

\begin{abstract}
Probiotics are the live microorganisms which when ingested in adequate amounts confer health benefits. The strains most frequently used as probiotics include Lactic acid bacteria, bifidobacteria and yeast Saccharomyces boulardii. However, several other bacterial strains are being investigated for potential probiotic value viz. Enterococcus, Streptococcus, Bacillus, among others. Significant therapeutic potential of probiotics has been demonstrated in several in vitro studies and that involving animal models and humans. Despite intense focus on probiotics research the mechanisms responsible for health benefits are not yet completely understood. Several important mechanisms have been proposed such as improvement of gut epithelial barrier function, Immunomodulatory effects, degradation of toxin receptors, competition for nutrients, production of inhibitory substances, antiproliferative effects, blocking of adhesion sites and modulation of gut microbiota. Bacterial cell components such as DNA or peptidoglycan may also be involved in functional mechanism of probiotics. Effectiveness of a probiotic for potential application as prophylactic or treatment agent for certain ailment is determined by its ability to possess all or most of these characteristic features. The current article describes the general functional mechanisms of probiotics.
\end{abstract}

Keywords: Probiotics, health benefits, functional mechanisms

\section{INTRODUCTION}

The concept of probiotics (as beneficial microorganisms replacing harmful microbes in the intestine by useful ones) dates back to the times of Elie Metchnikoff (1845-1916), a Russian professor of biology, who later worked as a director at the Institut Pasteur in Paris. Elie Metchnikoff is considered as the inventor of probiotics. Intrigued by the longevity of the Caucasian population and its frequent consumption of fermented milks, Metchnikoff proposed that the acidproducing organisms in fermented dairy products could prevent "fouling" in the large intestine and lead to a prolongation of the life span of the consumers (Smug et al., 2014). Although Metchnikoff's ideas were clearly related to lactic acid bacteria in dairy products, the interest of other scientists soon turned to lactic acid bacteria of intestinal origin. This observation initiated intensive research interest on probiotics. As a result probiotic concept expanded to include bacteria from intestinal origin in addition to those isolated from fermented dairy products 'Probiotics' is Greek word which means 'for life', and was initially defined by Fuller in 1989 as 'a live microbial feed supplement which beneficially affects the host by improving its microbial balance' (Fuller, 1989). Since then, severa broad definitions have been proposed by experts (Schrezenmeir and De Vrese, 2001) and by the Food and Agriculture Organization of the United Nations and World Health Organization (FAO/WHO, 2001). According to these definitions, probiotics are 'live microorganisms that, when ingested in adequate quantities, exert a health benefit to the host', by stimulating the growth of other microorganisms, modulating mucosal and systemic immunity, and improving the nutritional and microbial balance in the intestinal tract. Probiotics mostly include strains of lactic acid bacteria (Lactobacillus spp.) and Bifidobacterium spp. but also include certain yeast (Saccharomyces boulardii) and some other bacterial and yeast spp. (Bermudez-Brito et al., 2012; Bajaj et al., 2014). Safety of probiotic consumption is no issue as probiotics have been consumed in naturally fermented products since ancient times.

The health benefits associated with probiotic consumption have been extensively investigated in animal models and human studies, and include (Fig. 1) prevention and treatment of diarrhoeal disease (acute infantile diarrhoea, antibiotic associated diarrhoea, nosocomial infections), prevention of systemic infections, management of inflammatory bowel disease, immunomodulation, prevention and treatment of allergies, anticancer effects, treatment of cholesterolaemia, and alleviation of lactose intolerance (Gill and Guarner, 2004). Recently immense health benefits of probiotics have motivated the food industries to develop probiotic foods (Liong et al., 2011).

However, the health benefits of probiotics cannot be generalized as probiotics show huge differences at the level of genus, species and strains as far as their health benefitting attributes are concerned. The health benefits associated with one strain cannot be extrapolated to other strains without experimentation (Bermudez-Brito et al., 2012). Moreover one probiotics may not possess all the proposed health benefits. Monostrain probiotics are defined as probiotics containing one strain of a certain species, while multistrain probiotics contain more than one strain of the same species or closely related species, for instance Lactobacillus acidophilus and Lactobacillus casei. Multispecies probiotics are defined as strains of different probiotic species that belong to one or preferentially more genera, e.g. Lb. acidophilus, Bifidobacterium longum, Enterococcus faecium and Lactococcus lactis (Timmerman et al., 2004). The probiotic strain must tolerate and survive gastric and bile secretions during transit through the upper gastrointestinal tract and then flourish and colonize in the intestine. Metabolic products of the strain should not have any pathogenic, toxic, mutagenic, or carcinogenic reactions to the host. Probiotic strain must be genetically stable with no plasmid transfer mechanism. Furthermore, the probiotics must possess good technological properties to withstand and survive conditions during manufacturing, processing, storage and transport of the food products, and have a satisfactory level of viability at the time of consumption, (Schiffrin and Blum, 2001).

A major health challenge in developing countries is provision of diet which is augmented with physiological functional components that boost and maintain high immunity. This challenge is further complicated by high incidences of malnutrition, HIV-AIDS, and non complete diet and low sanitation. Furthermore, industrialization, urbanization, economic development and market globalization, had significant impact on the health and nutritional status of populations in the developed/developing world. To combat these challenges directly, WHO advocates the implementation of alternate disease control strategies such as exploiting prophylactic and therapeutic potential of probiotics (FAO/WHO, 2001).

Most probiotics delivery vehicles are based on dairy products which are very nutritious and satisfy the nutritional requirements of fastidious LAB, and have 
high acceptance among consumers. Probiotics have been incorporated in a wide range of dairy food products like milk, ice cream, yogurt, cheese, among others (Champagne et al., 2005; Kailasapathy et al., 2008; Daneshi et al., 2013). Physicochemical properties of food carriers used for probiotic delivery, such as buffering capacity, water activity, redox potential, protein, sugar content, $\mathrm{pH}$ and temperature are significant factors that influence survival of the probiotics during gastric transit. Cheeses have a strong potential for delivering probiotics due to their specific chemical and physical characteristics (Karimi et al., 2011). Ice cream and frozen dairy desserts have great potential as probiotic vehicles due to the lower storage temperature and less risk of temperature abuse (Cruz $\boldsymbol{e t}$ al., 2009). Dairy desserts such as chocolate mousse have also been considered as potential probiotic delivering agents (Possemiers $\boldsymbol{e t}$ al., 2010). However, due to some issues in dairy products like high cholesterol content, casein and cold storage, among others, there is substantial thrust on development of non-dairy food products as probiotic vehicles such as coconut milk, vegetable/fruit juices/drinks, nutrition bars, soy products and cereal-based products (Ranadheera et $\boldsymbol{a l} .$, 2010). The development of new non-dairy probiotic food products is demanding considering the consumer's expectancy for products that are simultaneously relish and healthy ( $\operatorname{Rad}$ et al., 2014).
Probiotics exert numerous health benefits on host through diverse mechanisms such as by influencing the composition and/or function of the commensa microbiota, altering host epithelial and immune system (Hyland et al., 2014), and by combating the toxins or products of microbial, food or host origin which may have ill effects on host health (Rupa and Mine, 2012; Sanders et al. 2013). Despite, the field of probiotics has made stupendous strides though there is no major breakthrough in the identification of the mechanisms by which probiotic strains enhance the health of the host. Intense research focus on mechanistic details of health benefits of probiotics is currently desired. The efficiency of probiotics often depends on the mechanism by which they exert their activity. By and large, to treat a disease, the probiotics follow a set of mechanisms and several studies have been done on how probiotics work. Figure 2 outlines some of the suggested general functional mechanisms for probiotics. So many mechanisms from these studies are trying to explain how probiotics could protect the host from the health disorders. The current article presents an over view of the various proposed mechanisms of probiotic action.

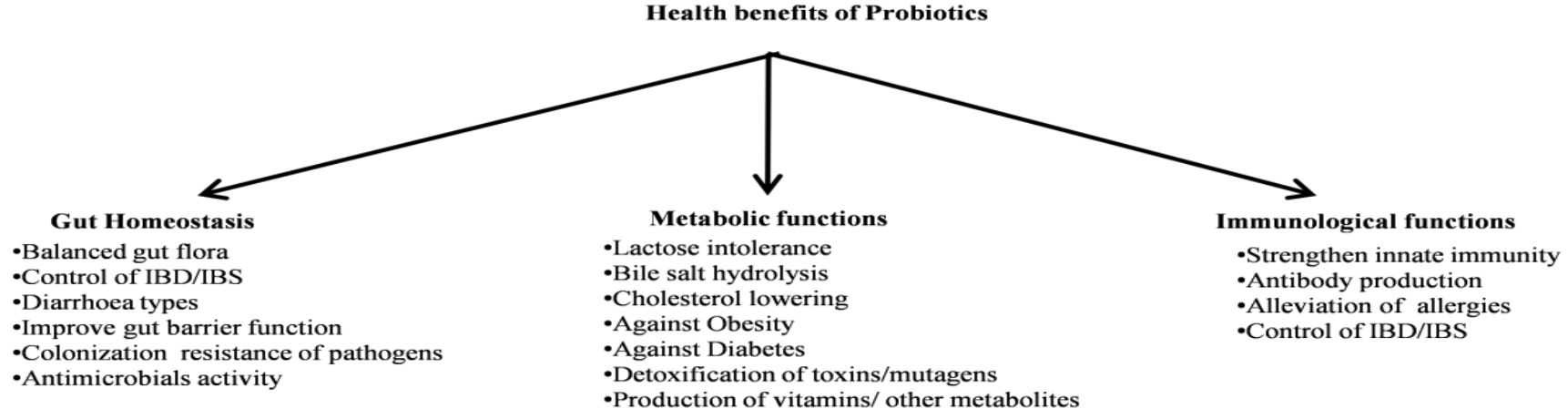

Figure 1 Health benefits of probiotics

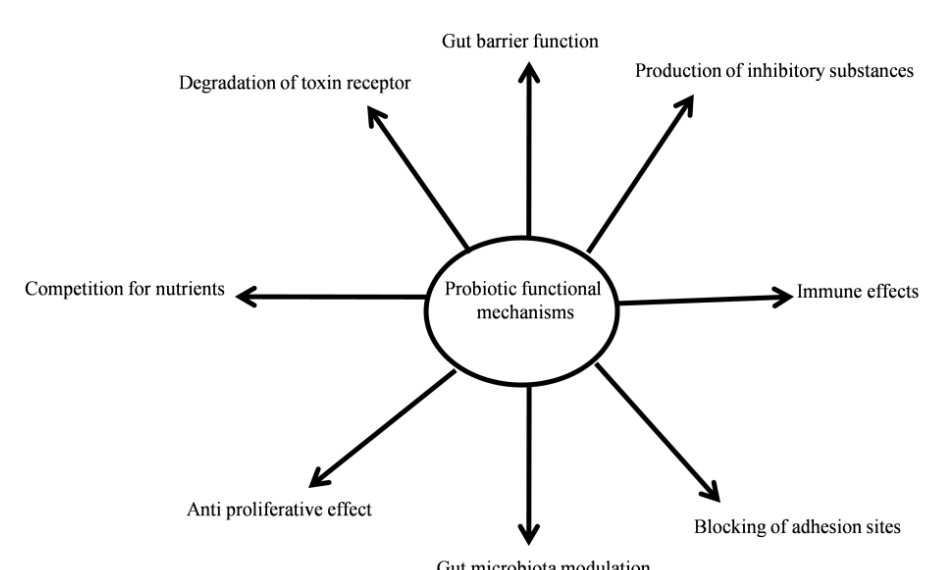

Gut microbiota modulation

Figure 2 Proposed functional mechanisms of probiotics

\section{PROBIOTICS ROLE ON THE GUT BARRIER FUNCTION}

The mucus layer, the epithelial lining of the mucosal tissues as well as the immune cells, present at sub-epithelial level, are all part of the mucosal barrier. Thus, modulation at all these levels can positively affect barrier robustness and thereby, influence disease states (Liu et al., 2011; Hyland et al., 2014). At cellular level, epithelial cells are at the centre stage of the barrier effect, receiving molecular signals from the gut lumen, exchanging signals with the underlying immune cells but also communicating with the entire organism by means of circulating signalling molecules. The gut barrier plays a crucial role in the pathogenesis of numerous gastrointestinal diseases such as inflammatory bowel disease (IBD), irritable bowel syndrome (IBS), coeliac disease and infectious enterocolitis (Blaut and Klaus, 2012). Therefore, selecting probiotic strains that can strengthen the gut barrier appears to be a relevant strategy with broad impact on different types of diseases (van Hemert et al., 2013).

Several studies using Caco-2 intestinal cells and mice showed that L. rhamnosus GG (LGG) or the probiotic mix VSL\#3 could interact directly with intestinal epithelial cells and maintain the integrity of the epithelial barrier. LGG persistence capacity in the GIT was linked to its in vivo expression of pili containing a mucus binding domain (Lebeer et $\boldsymbol{a l} .$, 2012). In addition, LGG and its soluble factors (p75 and p40) were shown to prevent epithelial cell apoptosis in vitro through activating anti-apoptotic Akt and suppression of NF-kB, and an additional effect observed in the study was that LGG enhances mucin secretion by epithelial cells (Yan and Polk, 2002). These effects can potentially contribute to pathogen exclusion and maintenance of homeostasis if reproducible in vivo. In addition, it shows that probiotic strains affect the same tissue -in this case the epithelium - by different pathways, all contributing to the preservation of the barrier effect. In the clinical context, administration of Lactobacillus plantarum in the small intestine of healthy subjects induce structural changes in epithelial tight junctions, resulting in increased tight junction specific proteins occludin and zonula occludens-1. Since loss of tight junction integrity and the resulting increased intestinal permeability to macromolecules are associated with several diseases such as IBD, IBS and coeliac disease, the data obtained with the L. plantarum strain provide relevant information towards an intervention in the corresponding subjects (Sawada et al., 2003).

Treatments with several spp. and strains of Lactobacillus such as L. plantarum, $L$. acidophilus, L. casei, and L. rhamnosus induce differential gene-regulatory networks and pathways in the human mucosa involving up-regulation of IL-1b, an activator of NF-kB signalling cascade, which may drive the transcription of genes involved in lymphogenesis and B-cell maturation, thus contributing to enhancement of barrier function. Differential expression of genes involved in wound repair and healing, angiogenesis, IFN response, calcium signalling and ion homeostasis, are relevant for the vascularization/nourishment of epithelial cells (van Baarlen et al., 2011). Furthermore, the observed changes in transcriptional networks display similarity with responses obtained with bioactive molecules and drugs, which reflect upon potential novel application of probiotics in areas of therapeutic and/or prophylactic nutritional regimes.

Probiotics like Bifidobacterium, Lactobacillus, and Streptococcus show curative effects on post-infectious irritable bowel syndrome (PI-IBS) induced by Trichinella spiralis in a mouse model. Bifidobacterium or Lactobacillus treated PI-IBS mice exhibited decreased abdominal withdrawal reflex score and contractile response, reduced plasma diamine oxidase (DAO) and D-lactate Furthermore, probiotic treatments suppressed the expression of proinflammatory cytokine IL-6 and IL-17 and promoted the expression of major tight junction proteins claudin-1 and occludin. The mixture of the three probiotic strains performed better than the individual in up-regulating these tight junction proteins and suppressing IL-17 expression (Wang et al., 2014).

\section{PRODUCTION OF INHIBITORY SUBSTANCES BY PROBIOTICS}

Probiotics exert antibacterial effects against pathogenic and/or food spoilage gram-positive and gram-negative bacteria through production of antibacterial substances such as bacteriocins, organic acids, hydrogen peroxide, among others (Arauz et al., 2009; Razdan et al., 2012; Bajaj et al., 2014; Bajaj et al., 2014; 
Dec et al., 2014). Probiotic-derived antibacterial substances show their effects individually or synergistically to inhibit the growth of pathogenic bacteria. Probiotics have been reported to produce a wide range of different bacteriocins such as nicin (Arauz et al., 2009) which constitute the major mechanism for their antimicrobial action. Lactobacillus acidophilus has been reported to produce acidophillin, lactocidin, and acidolin and Lactobacillus planatarum produces lactolin (Vila et al., 2010). Bacteriocin produced by probiotic strain Lactobacillus salivarius UCC118, protect the mice against infection with the invasive foodborne pathogen Listeria monocytogenes. From the studies it was also confirmed that antimicrobial effect was mediated by the bacteriocin Abp118 produced by direct antagonism between $L b$. salivarius and the pathogen (Corr $\boldsymbol{e}$ al., 2007). Lactobacilli and bifidobacteria have been shown to inhibit a broad range of pathogens, including E. coli, Salmonella, Helicobacter pylori, Listeria monocytogenes and Rotavirus (Bermudez-Brito et al., 2012). Bacteriocin produced by Gram-positive bacteria have a narrow activity spectrum and act only against closely related bacteria, however, some bacteriocins inhibit food-borne pathogens like Listeria monocytogenes (Nielsen et al., 2010).

Several Bifidobacterium strains have been reported to produce a unique bacteriocin (bifidocin B, from B. bifidum NCFB 1454) which is active towards Gram-positive bacteria. Two Bifidobacterium strains exhibited a strong killing activity against several pathogenic bacteria, including Salmonella enterica ser. Typhimurium SL1344 and E. coli C1845 (Bermudez-Brito et al., 2012). Twenty Lactobacillus strains inhibited enteropathogenic Yersinia enterocolitica while two strains Lactobacillus casei $\mathrm{C} 1$ and Lactobacillus plantarum $\mathrm{C} 4$ inhibited Salmonella enterica serovar Typhimurium and Listeria monocytogenes in addition to $Y$. enterocolitica. Mechanism of inhibition was decrease in $\mathrm{pH}$ resulting from dextrose fermentation by lactobacilli. However, protective effects of these probiotic strains could not be established in mouse experimenta infection models against $S$. Typhimurium. Although L. plantarum C4 showed partial protective effect that was attributable to an immunostimulatory mechanism. Thus, in vitro study of antibiosis may provide useful information on the probiotic potential of Lactobacillus strains (Bujalance et al., 2014).

The common mechanisms of bacteriocin-mediated killing include the destruction of target cells by pore formation and/or inhibition of cell wall synthesis. For example, nisin forms a complex with the ultimate cell wall precursor, lipid II, thereby inhibiting cell wall biosynthesis, and subsequently, the complex aggregates and incorporates peptides to form a pore in the bacterial membrane. Bacteriocin production confers producing strains with a competitive advantage within complex microbial environments as a consequence of their associated antimicrobial activity, and at the same time inhibits pathogens in GI tract (Nielsen et al., 2010; Hassan et al., 2012; O'Shea et al., 2012).

\section{BLOCKING OF ADHESION SITES BY PROBIOTICS}

Adhesion to intestinal mucosa is one of the major selection attribute for probiotics as it is required for intestinal colonization, and is also important for modulation of the immune system and antagonism against pathogens. Lactic acid bacteria (LAB) display various surface determinants that are involved in their interaction with intestinal epithelial cells and mucus which help competitive exclusion of pathogens from the mucus. Several Lactobacillus proteins (along with saccharide moieties and lipoteichoic acids) have been shown to promote mucous adhesion (Van Tassell and Miller, 2011; Bermudez-Brito et al., 2012) and bacteria display surface adhesions that mediate attachment to the mucous layer. Bacterial adhesins (MUB, mucus-binding protein) have been reported from Lactobacillus reuteri (Buck et al., 2005). Probiotics, such as L. plantarum, have been reported to induce MUC2 and MUC3 mucins and to inhibit the adherence of enteropathogenic E. coli. Thus, enhanced mucous layers and glycocalyx overlying provides protection against pathogen invasion. Furthermore, probiotic organisms adhere to intestinal gut epithelial surfaces and block the adhesion sites, therefore, prevent colonization of pathogenic bacteria (Ohland and MacNaughton, 2010). When lactobacilli are ingested, they compete for binding sites, leaving less binding sites open for pathogens. Pathogens pass through gut and leave the body sooner when no binding site is available. Adhesion of L. plantarum Lp6 to rat mucus is mediated by the mannose specific adhesion proteins that reversibly bind to the cell surface components and important for competing with pathogens binding sites in gut, and therefore, resist the colonization of the pathogens (Sun et al., 2007). Acidresistant strains of Bifidobacterium longum and B. catenulatum showed better adhesion to human intestinal mucus as compared the acid-sensitive strains (Collado et al., 2005). Acid resistance in bifidobacteria enhances potential functionality by improving stability and surface properties. The mixture of probiotics and VSL\#3 enhance the synthesis of cell surface mucins and modulate mucin gene expression thus improving the adhesion of bacterial cells to the intestinal epithelium (Caballero-Franco et al., 2007). Candidate probiotics Lactobacillus reuteri ATCC 55730, Lactobacillus rhamnosus AC413, but not L. salivarius, reduced Staphylococcus aureus -induced keratinocyte cell death in both undifferentiated and differentiated keratinocytes. Keratinocyte survival was significantly higher if the probiotic was applied prior to or simultaneously with infection with $S$. aureus. S. aureus utilizes the $\alpha 5 \beta 1$ integrin to adhere to keratinocytes, and blocking of this integrin resulted in a protective effect similar to that observed with probiotics. This suggests that the protective mechanism for $L$. reuteri-mediated protection of keratinocytes was by competitive exclusion of the pathogen from its binding sites on the cells. Thus use of a topical probiotic prophylactically could inhibit the colonization of skin by $S$. aureus and aid in the prevention of infection (Prince et al., 2012).

\section{ROLE OF PROBIOTICS IN COMPETITION FOR NUTRIENTS}

Competition for nutrients may be one of the mechanisms for colonisation resistance of pathogens in human gut. When health promoting bacteria are present in the gut, they utilize more nutrients, leaving fewer nutrients for pathogenic bacteria, which may suffer starvation, and not survive. The competitive exclusion takes place in two ways; firstly inhibiting the pathogens by consuming the nutrients and energy source which pathogens need, thus preventing them from proliferation and growth in the gut environment. Second is producing several organic acids and volatile fatty acids because of their metabolism and fermentation, resulting in lowering of the gut $\mathrm{pH}$ below that essential for pathogenic bacteria e.g. Salmonella and E. coli (Bermudez-Brito et al., 2012). Continuous flow culture model of the mouse caecal flora was used to investigate the colonisation resistance against Clostridium difficile. It was reported that the levels of carbohydrates within a continuous flow culture colonised with mouse intestinal flora were insufficient to support $C$. difficile growth. In particular, it appeared that an unidentified organism competed more efficiently than $C$. difficile for monomeric glucose, $\mathrm{N}$-acetylglucosamine, and sialic (N-acetylneuraminic) acid in the continuous flow culture model (Wilson and Perini, 1988). Probiotics may similarly over compete with pathogens for nutrients, and cause exclusion of pathogens and, thus providing protection to the host. Thus, competition for nutritional substrates amongst probiotics, intestinal pathogens and microbiota may play a significant role. Bifidobacterium adolescentis S2-1 compete with Porphyromonas gingivalis for utilization of vitamin $\mathrm{K}$ other growth factors (Hojo et al., 2007), and inhibit growth of $P$. gingivalis. Germ-free mice colonised with human baby microbiota, showed diverse alteration of pathways including the metabolism of amino acid, methylamines and short chain fatty acids (SCFA) upon exposure to a probiotic strain of Lactobacillus paracasei or Lactobacillus rhamnosus (Martin et al., 2008).

Iron constitute one of the essential nutrients for most of the bacteria, is often available in limited amounts. However, lactobacilli not require iron and hence have edge over other iron requiring bacteria (pathogens); furthermore, some probiotics such as $L$. acidophilus and $L$. delbrueckii bind ferric hydroxide at their cell surface, and make it unavailable to pathogenic microorganisms (Elli $\boldsymbol{e t}$ al., 2000). Thus, probiotic bacteria alter the physical environment in such a way that the pathogenic bacteria cannot survive. Probiotic strains L. paracasei and L. rhamnosus exert inhibitory effects on pathogens Salmonella typhimurium and Listeria monocytogenes biofilm formation by mechanism involving competition, exclusion and displacement. L. monocytogenes biofilm cells were reduced by more than $3 \log$ cycles (Woo and Ahn, 2013).

\section{IMMUNE EFFECTS OF PROBIOTICS}

Different pathways have been identified by which probiotics modulate immune system (van Hemert et al., 2013; Hyland et al., 2014). One possible mechanism of probiotics to protect the host from intestinal disease is by stimulating specific and nonspecific immunity. LAB products exert immunomodulatory activity via inhibition of inflammatory responses, regulation of the expression of TLRs (Toll like Receptors), activation of DCs (Dendritic cells) and NK (Natural Killer) cells in innate immunity; proliferation of lymphocytes, balancing T-helper (Th1/Th2) cells responses, secretion of specific IgA, among several other ways (Tsai $\boldsymbol{e t}$ al., 2012). Role of Saccharomyces boulardii and Bacillus subtilis B10 play a potential role in modulating immunological functions of chicken bone marrow dendrite cells by targeting specific toll like receptors (TLRs) and associated factors. Probiotics attached on the surface of dendrite cells. Gene expression levels of MHC-II, CD40, CD80 and CD86 was up-regulated. Furthermore, tolllike receptors TLR1, TLR2, TLR4, and chicken specific TLR15 expressions were improved and downstream associated factors MyD88, TRAF6, TAB1, and NFאB mRNA levels increased (Rajput et al., 2014).

Probiotic bacteria exert its beneficial effects and modulate the immune system of the host against potentially harmful antigens via activation of lymphocytes and production of antibodies. The colonization of healthy microbes leads to maturation of the humoral immune mechanisms, particularly circulation of the IgA and IgM secreting cells. After priming, memory B and T cells migrate to effectors sites followed by active proliferation, local induction of certain cytokines and production of secretory antibodies $\operatorname{IgA}$. The entrance of probiotics in the gut stimulates the production of IgA. The production of $\operatorname{IgA}$ in the immune system has become clear from the studies performed in mice, which are kept germ-free after birth (Ng et al., 2009). A lot of reports showed that lactic acid bacteria (LAB) as Lactobacillus and Bifidobacterium and their fermented products are effective at enhancing innate and adaptive immunity, prevent gastric mucosal lesion development, alleviate allergies, and put up defense against intestinal pathogen infection (Tsai et al., 2012). 
Lactobacilli also stimulate immune cells to release pro-inflammatory cytokines such as tumor necrosis factor-alpha (TNF- $\alpha$ ), interferon-gamma (IFN- $\gamma$ ), and interleukin-12 (IL-12). Mechanisms of innate immunity include enhancement of antigen presentation, phagocytosis on antigen presenting cells (APCs), and cytotoxicity by natural killer (NK) cells, all of which can kill transformed cells in a seemingly nonspecific fashion. DCs play a crucial immunoregulatory role in immune responses under antigen uptake and processing, such as the induction of Ag-specific immune responses and Th1/Th2 balance. Probiotics regulate secreted cytokines by DC to improve the morbidity of intestinal diseases (Tsai $\boldsymbol{e t}$ al. 2012). Oral administration of Lactobacillus enhances specific adaptive immune responses through innate immunity in mice (Paturi et al., 2007). The interaction between CD40 and CD154 on DCs and CD4+ T cells, respectively, induces the priming and expansion of $\mathrm{CD} 4+\mathrm{T}$ cells, and subsequently leads to activation, proliferation, and differentiation (Grewal and Flavell, 1998). The immunomodulation of gut mucosal immunity by Lactobacillus species induces B cell migration and protective IgA production through intestinal DC modulation (Mora et al., 2006). Several Lactobacillus strains have the effect of skewing T cells from $\mathrm{T}$ helper 2 (Th2) toward Th1 responses, thus promoting humoral immunity (Mohamadzadeh et al., 2005). Many types of LAB products have anti-allergic effects in a murine model. Recent research demonstrates that the $L$ rhamnosus GG derived soluble protein p40 activates EGFR to inhibit cytokineinduced apoptosis and disrupted barrier in intestinal epithelial cells. Furthre, i also showed the effects of LGG p40 through EGFR activation play a significant role, in the development of probiotic-derived proteins as novel reagents for protecting the intestine from injury and inflammation (Yan et al., 2011) Supplementation of the diet with probiotics can persistently modulate both innate and adaptive immune responses locally and systemically. Up-regulation of helpe $\mathrm{T}$ cell activation induces stronger $\mathrm{DC} / \mathrm{NK}$ and $\mathrm{DC} / \mathrm{CD} 4+\mathrm{T}$ cell interaction, lymphocyte proliferation, and cytokine expression (Tsai et al., 2012)

Lactobacillus rhamnosus-feeding to 16 months old mice resulted in alleviated immunosenescence-associated Th1/Th2 imbalance, improved antioxidant capacity, and enhanced resistance of aged mice to $E$. coli infection. In probiotic fed mice splenocytes showed increased IFN- $\gamma$ and decreased IL-4 and IL-10 production, neutrophil respiratory burst enzymes and phagocytosis increased while no aggravation in plasma levels of MCP-1 and TNF- $\alpha$ occurred, IgG1/IgG2a ratio and IgE levels decreased, antioxidant enzymes activities increased and E. coli translocation to organs significantly reduced (Sharma $e t$ al., 2014).

\section{ROLE OF PROBIOTICS IN DEGRADATION OF TOXIN RECEPTORS}

Probiotics modify toxin receptor through an enzymatic mechanism, because of the degradation of toxin receptor on the intestinal mucosa Saccharomyces boulardii protects the host against Clostridium difficile intestinal disease. Some other offered mechanisms are suppression of toxin production, reduction of gut $\mathrm{pH}$, attenuation of virulence (Bermudez-Brito et al., 2012). Probiotics can also modify toxin receptors and block toxin-mediated pathology. Saccharomyces boulardii degrades Clostridium difficile toxin receptors in the rabbit ileum and blocks cholera-induced secretion in rat jejunum by the production of polyamines. Probiotics may also promote nonspecific stimulation of the host immune system, including immune cell proliferation, enhanced phagocytic activity of macrophages, and increased production of secretory immunoglobulin $\operatorname{Ig} \mathrm{A}$ and IgM (Kaur et al., 2009). The protective effect of a multi-strain probiotic and synbiotic formulation (Lactobacillus plantarum $\mathrm{F} 44, \quad$ L. paracasei $\mathrm{F} 8$, Bifidobacterium breve 46, B. lactis 8:8, galacto-oligosaccharides, isomaltooligosaccharides and resistant starch) was evaluated in C57BL/6 mice infected with Clostridium difficile NAP1/027. Feeding of the formulation resulted in increase of total bifidobacteria and lactobacilli counts, and absolutely no caecal toxins were detected. qPCR of caecal content showed significant reduction in $C$. difficile DNA copies (Kondepudi et al., 2014).

\section{ANTI PROLIFERATIVE EFFECT OF PROBIOTICS}

Probiotics have been claimed to possess anti-cancer activity which may be attributed to the reduction of putrefactive bacteria like Clostridium, coliforms or Bacteroides species and an enhanced level of lactobacilli and bifidobacteria that help reducing incidence for colorectal cancer. The incidence of adenocarcinoma in the colon of IL-10 knockout mice was factually reduced in mice treated with probiotic Lactobacillus salivarius ssp. salivarius (O'Mahony et al., 2001) Treatment with probiotics able to interfere with chronic recurrent inflammation of the gut might also be helpful in preventing colon carcinoma, because chronic inflammation promotes the appearance of this disease. An example of an anti inflammatory active probiotic is Streptococcus thermophilus strain TH-4 which also produces high amounts of folate important for DNA repair in epithelial cells (Van Guelpen et al., 2006; Tooley et al., 2006).

Marked anti-mutagenic activity of many lactobacilli, some bifidobacteria strains may be due to their ability to metabolically inactivate the mutagenic substances Furthermore, certain probiotics bind N-nitroso compounds and heterocyclic aromatic amines. This can lead to reducing the levels of carcinogenic compounds and reducing DNA damage (Geier et al., 2006).
Another mechanism for anti-tumour activity of probiotics may be due to their ability to amplify the immune response to tumour tissue by modulation of cytokine production and $\mathrm{T}$ cell function (Hirayama and Rafter, 2000). Administration of the cytoplasmic fraction of L. acidophilus SNUL, L. case YIT9092 and B. longum HY8001 lead to reduction of tumour cell proliferation in vitro and increased survival rate of mice injected with tumour cells (Lee $\boldsymbol{e t}$ al. 2004). Peptidoglycan from Lactobacillus species reduced in a dosedependent manner growth of CT26 cancer cells originating from the colon of BALB/C mice by increasing apoptosis (Sun et al., 2005). Factors secreted by Lactobacillus reuteri ATCC PTA 6475 potentiated apoptosis in myeloid leukemia-derived cells induced by tumour necrosis factor (Chandra et al., 2008). Lactobacillus and Lactococcus strains isolated from food products can be introduced as probiotics because of their health-promoting characteristics including anticancer activity. Cytotoxicity assessments of Lactococcus lactis subsp. Lactis 44Lac were used to analyze the effects of the secreted metabolite on different cancer cell lines, including HT29, AGS, MCF-7, and HeLa, as well as a normal human cell line (HUVEC). Results showed acceptable cytotoxic properties for secreted metabolites ( $40 \mu \mathrm{g} / \mathrm{ml}$ dry weight) of Lactococcus lactis subsp. Lactis 44Lac. Such performance was similar to that of Taxol against all of the treated cancer cell lines; however, the strain exhibited no toxicity on the normal cell line. Cytotoxic assessments through flow cytometry and fluorescent microscopy demonstrated that apoptosis is the main cytotoxic mechanism for secreted metabolites of L. lactis subsp. Lactis 44Lac. By contrast, the effects of protease-treated metabolites on the AGS cell line verified the protein nature of anti-cancer metabolites. However, precise characterizations and in vitro/in vivo investigations on purified proteins should be conducted before these metabolites are introduced as potential anti-cancer therapeutics (Haghshenas et al., 2014).

\section{PROBIOTICS FOR GUT MICROBIOTA MODULATION}

Gut microbiota has been involved in regulating several physiological functions, ranging from energy regulation and cognitive processes to toxin neutralization and immunity against pathogens. Development and onset of various chronic diseases occurs when there is alteration in the composition of the gut microbiota Studies have shown that gut microbiota play a critical role in the development of different disease conditions, including obesity, fatty liver disease, and lung infection. Interventions with the potential application of prebiotics and probiotics helps maintaining optimal gut health, and preventing/treating chronic inflammatory and immunity related diseases (Lin et al., 2014). Potential health benefits of probiotics may be due to direct effects of probiotic cells, by means of secreted cell components, metabolic effects and cell to cell interactions. The impact of probiotics strains on the human GIT microbiota seems to play a very important role in the gut microbial network interactions. Probiotic bacteria generally ingested at a level of $10^{8-9}$ cells, reach the colon in an amount based on survival rate in stomach and small intestine. The impact of ingested probiotics on the colonic environment is essentially attributed to the fecal persistence of the ingested strains. They colonize the gut temporarily and disappear once the consumption stops. Modulation of commensal microbiota by transiting probiotics can be expected due to antimicrobial compounds with broad spectrum such as reuterin or plantaricins or indirectly through modulation of the immune system or gut barrier function. Use of probiotics has been reported in the prevention of antibiotic-induced diarrhea, and acute infectious diarrhea, and helpful in other gut related disease such as IBS or colics that have been associated with microbiota dysbiosis; the gut microbial community composition remains more stable during the period of probiotics treatment and that it positively correlates with improvement of disease symptoms (Ceapa et al., 2013). Most evidence available on the impact of probiotics on the microbiota composition and functions has been obtained by using methods targeting specific bacterial genera like Lactobacillus and Bifidobacterium while this type of nutrition may have very subtle influence on other relevant genera as well (Rautava et al., 2012).

Microbiota dysbiosis in immune-related disease such as allergy or IBD can be managed by a successful probiotic intervention which may be associated with a targeted modulation of the microbiota to repress specific pathobionts or stimulate endogenous beneficial groups on top of direct molecular interaction with immune cells in the small intestine. Transiting probiotics are therefore not always expected to affect the global intestinal microbiota structure in a major way, but rather to directly modulate with the immune system and miscellaneous epithelial receptors all along the digestive tract. As a consequence low abundance but metabolically active bacteria can still be meaningful in microbiota modulation, by for example modulating existing microbiota-interactive metabolic networks All evidence taken together, probiotic strains that are able to combine specific and direct interaction with the host with transient impacts on the residing microbiota can elicit complex multifaceted but more optimal health (Bajaj et al., 2014; ; Ceapa et al., 2013; Lin et al., 2014). Role of probiotics in correcting dysbiosis of the normal microbiota resulting from disease or disruptive events was reviewed (McFarland, 2014) based on the studies published on probiotic intervention for the prevention or treatment of various diseases. The outcome was the degree of microbiota correction by specific probiotic strains, and the association between the degree of dysbiosis correction and clinical efficacy. Assessment of the degree of dysbiosis improvement was dependent on the 
enrolled population and the timing of microbiological assays. However, the functional claim for correcting dysbiosis was poorly supported for most probiotic strains and necessitates further research.

Although numerous studies have been conducted more insight is needed for the characterization of a 'normal' microbiota at a functional level, screening for probiotic strains with a high protective potential is necessary, the mechanisms of action of single probiotic strains and combinations are essential for their use in the clinical practice, and finely the clinical studies with better design and larger cohorts are necessary to support concepts fitting in the 'health by means of diet' concept.

\section{CONCLUSION}

Though probiotics have significant therapeutic and/or prophylactic potential in various gastrointestinal or other diseases/disorders. However, several of the health claims of probiotics are yet to be established experimentally through animal models/human studies, and underlying mechanisms of action still needs to be fully elucidated. Moreover, the functional role of gut microbiota and potential invention by probiotics has yet to be worked out for human health and disease The current article attempted to review the available scientific information on mechanisms of action of probiotics. Major health-benefitting mechanisms of probiotics included enhanced gut epithelial barrier function, Immunomodulatory effects, degradation of toxin receptors, competition for nutrients, production of inhibitory substances, antiproliferative effects, blocking of adhesion sites, modulation of gut microbiota, among others.

Acknowledgements: Dr. Bijender K Bajaj gratefully acknowledges VLIR-UOS (Govt. of Belgium) for Short Research Stay-SRS-Scholarship at Department of Bioscience Engineering, University of Antwerp, Antwerpen, Belgium, and the Director, School of Biotechnology, University of Jammu, Jammu, for necessary Laboratory facilities for initiating probiotics research.

\section{REFERENCES}

ARAUZ, L.J., JOZALAA, A.F., MAZZOLAB, P.G., VESSONI, PENNAA, T.C 2009. Nisin biotechnological production and application: a review. Trends Food Sci. Technol. 20, 146-154. http://dx.doi.org/10.1016/j.tifs.2009.01.056

BLAUT, M., KLAUS, S. 2012. Intestinal microbiota and obesity. Handb. Exp. Pharmacol. 209, 251-273. http://dx.doi.org/10.1007/978-3-642-24716-3_11.

BAJAJ, B.K. RAZDAN K., CLAES I.J.J., LEBEER, S. 2014. Characterization of exopolysaccharides of potential probiotic Enterococcus faecium isolates from infants'gut. Current Biochemical Engineering, (Accepted).

BAJAJ, B.K. RAZDAN K., CLAES I.J.J., LEBEER, S. 2014ª . Probiotic attributes of the newly isolated lactic acid bacteria from infants'gut. J. Microbiol. Biotechnol. Food Sci. (submitted)

BERMUDEZ-BRITO, M., PLAZA-DÍAZ, J., MUÑOZ-QUEZADA, S. GÓMEZ-LLORENTE, C., GIL, A. 2012. Probiotic Mechanisms of Action. Ann. Nutr. Metab. 61, 160-174. http://dx.doi.org/10.1159/000342079

BRON, P.A., TOMITA, S., VAN SWAM, I.I., REMUS, D.M., MEIJERINK M., WELS, M., OKADA， S., WELLS， J.M., KLEEREBEZEM， M. 2012 Lactobacillus plantarum possesses the capability for wall teichoic acid backbone alditol switching. Microb Cell Fact.11, 123. http://dx.doi.org/10.1186/14752859-11-123

BUCK, B.L., ALTERMANN, E., SVINGERUD, T., KLAENHAMMER, T.R. 2005. Functional analysis of putative adhesion factors in Lactobacillus acidophilus NCNCFM. Appl. Environ. Microbiol. 71, 8344-8351. http://dx.doi.org/10.1128/aem.71.12.8344-8351.2005

BUJALANCE， C., JIMÉNEZ-VALERA， M., MORENO， E., RUIZ-LÓPEZ M.D., LASSERROT, A., RUIZ-BRAVO, A. 2014. Lack of correlation between in vitro antibiosis and in vivo protection against enteropathogenic bacteria by

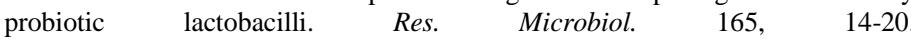
http://dx.doi.org/10.1016/i.resmic.2013.10.006

CABALlERO-FRANCO, C., KELLER, K., DE SIMONE, C., CHADEE, K. 2007. The VSL\#3 probiotic formula induces mucin gene expression and secretion in colonic epithelial cells. Am. J. Physiol. Gastrointest. Liver Physiol. 292, G315-G322. http://dx.doi.org/10.1152/ajpgi.00265.2006

CEAPA, C., WOPEREIS, H., REZAÏKI, L., KLEEREBEZEM, M., KNOL J., OOZEER, R. 2013. Influence of fermented milk products, probiotics and probiotics on microbiota composition and health. Best Pract. Res. Clin. Gastroenterol. 27, 139-155. http://dx.doi.org/10.1016/j.bpg.2013.04.004

CHANDRA, I., KOSTERS, A., SETHI, G., KUNNUNMAKKARA, A.B. AGGARWAL, B.B., VERSALOVIC, J., 2008. Probiotic Lactobacillus reuter promotes TNF-induced apoptosis in human myeloid leukemia-derived cells by modulation of NF-kB and MAPK signalling. Cell. Microbiol. 10, 1442-1452. http://dx.doi.org/10.1111/j.1462-5822.2008.01137.x

CHAMPAGNE, C.P., ROY, D., GARDNER, N., 2005. Challenges in the addition of probiotic cultures to foods. Crit. Rev. Food Sci. Nutr. 45, 61-84.

COLLADO, M.C., GUEIMONDE, M., SANZ, Y., SALMINEN, S. 2006. Adhesion properties and competitive pathogen exclusion ability of bifidobacteria with acquired acid resistance. J. Food Prot. 69, 1675-1679.
CORR, S.C., LI, Y., RIEDEL, C.U., O'TOOLE, P.W., HILL, C., GAHAN, C.G. 2007. Bacteriocin production as a mechanism for the antiinfective activity of Lactobacillus salivarius UCC118. Proc. Natl. Acad. Sci . 104, 7617-7621. http://dx.doi.org/10.1073/pnas.0700440104

CRUZ, A.G., ANTUNES, A.E.C., SOUSA, A.L.P., FARIA, J.A.F., SAAD, S.M.I. 2009. Ice-cream as probiotic food carrier. Food Res. Int. 42, 1233-1239. http://dx.doi.org/10.1016/i.foodres.2009.03.020.

DANESHI, M., EHSANI, M.R., RAZAVI, S.H. LABBAFI, M. 2013. Effect of refrigerated storage on the probiotic survival and sensory properties of milk/carrot juice mix drink. Electron. J. Biotechnol. 16, 1-12. http://dx.doi.org/10.2225/vol16-issue5-fulltext-2

DEC, M., PUCHALSKI, A., URBAN-CHMIEL, R., WERNICKI, A. 2014 Screening of Lactobacillus strains of domestic goose origin against bacterial poultry pathogens for use as probiotics. Poult Sci. 2014 93, 2464-2472. http://dx.doi.org/10.3382/ps.2014-04025.

ELLI, M., ZINK, R., RYTZ, A., RENIERO, R., MORELLI, L., 2000. Iron requirement of Lactobacillus spp. in completely chemically defined growth media. J. Appl. Microbiol. 88, 695-703. http://dx.doi.org/10.1046/j.13652672.2000.01013.x

Food and Agriculture Organization of the United Nations/World Health Organization (FAO/WHO). Report of a Joint FAO/WHO Expert Consultation on evaluation of health and nutritional properties of probiotics in food including powder milk with live lactic acid bacteria, 1-4 October 2001, Córdoba, Argentina. p. 19-20.

FULLER, R. 1989. Probiotics in man and animals. J. Appl. Bacteriol. 66, 365 378. http://dx.doi.org/10.1111/j.1365-2672.1989.tb05105.x

GEIER, M.S., BUTLER, R.N., HOWARTH, G.S. 2006. Probiotics, prebiotics and synbiotics. A role in chemoprevention of colorectal cancer?. Cancer Biol. Ther. 5, 1265-1269. http://dx.doi.org/10.4161/cbt.5.10.3296.

GILL, H.S., Guarner, F. 2004. Probiotics and human health: a clinical $\begin{array}{llll}\text { perspective. } & \text { Postgrad. } & \text { Med. } & \text { J. 80, }\end{array}$ http://dx.doi.org/10.1136/pgmj.2003.008664.

GREWAL, I.S., FLAVELL, R.A. 1998. CD40 and CD154 in cell-mediated immunity. Annu. Rev. Immunol.16, 111-135. http://dx.doi.org/10.1146/annurev.immunol.16.1.111.

HAGHSHENAS, B., ABDULLAH, N., NAMI, Y., RADIAH, D., ROSLI, R., KHOSROUSHAHI, A.Y. 2014. Different effects of two newly-isolated probiotic Lactobacillus plantarum $15 \mathrm{HN}$ and Lactococcus lactis subsp. Lactis 44Lac strains from traditional dairy products on cancer cell lines. Anaerobe 30 51-59. http://dx.doi.org/10.1016/j.anaerobe.2014.08.009.

HASSAN, M., KJOS, M., NES, I.F., DIEP, D.B., LOTFIPOUR, F. 2012 Natural antimicrobial peptides from bacteria: characteristics and potential applications to fight against antibiotic resistance. J. Appl. Microbiol. 113, 723726. http://dx.doi.org/10.1111/j.1365-2672.2012.05338.x

HIRAYAMA, K, RAFTER, J, 2000. The role of probiotic bacteria in cancer prevention. Microbes Infect. 2, 681-686. http://dx.doi.org/10.1016/s1286-4579 (00)00357-9.

HOJO, K., NAGAOKA S., MURATA S., TAKETOMO N., OHSHIMA T. MAEDA N. 2007. Reduction of vitamin K concentration by salivary Bifidobacterium strains and their possible nutritional competition with Porphyromonas gingivalis. J. Appl. Microbiol. 103, 1969-1974 http://dx.doi.org/10.1111/j.1365-2672.2007.03436.x

HYLAND, N.P., QUIGLEY, E.M. BRINT, E. 2014. Microbiota-host interactions in irritable bowel syndrome: Epithelial barrier, immune regulation and brain-gut interactions. World J. Gastroenterol. 20, 8859-8866.

KAILASAPATHY, K., HARMSTORF, I., PHILLIPS, M. 2008. Survival of Lactobacillus acidophilus and Bifidobacterium animalis ssp. lactis in stirred fruit yogurts. $\quad$ LWT-Food Sci. Technol.41, 1317-1322. http://dx.doi.org/10.1016/j.lwt.2007.08.009

KAUR, I.P., KUHAD, A., GARG, A., CHOPRA, K. 2009. Probiotics: Delineation of Prophylactic and Therapeutic Benefits. J. Med. Food 12, 219 235. http://dx.doi.org/10.1089/jmf.2007.0544.

KELLY, D., DELDAY, M.I., MULDER, I. 2012. Microbes and microbial effector molecules in treatment of inflammatory disorders. Immunol. Rev. 245 27-44. http://dx.doi.org/10.1111/j.1600-065x.2011.01079.x.

KARIMI, R., MORTAZAVIAN, A.M., CRUZ, A.G.D. 2011.Viability of probiotic microorganisms in cheese during production and storage: a review. Dairy Sci. Technol. 91, 283-308. http://dx.doi.org/10.1007/s13594-011-0005-x

KONDEPUDI, K.K., AMBALAM, P., KARAGIN, P.H., NILSSON I., WADSTRÖM, T., LJUNGH, A. 2014. A novel multi-strain probiotic and synbiotic supplement for prevention of Clostridium difficile infection in a murine model. Microbiol. Immunol. http://dx.doi.org/10.1111/1348-0421.12184.

LIU, Z., QIN, H., YANG, Z., XIA, Y., LIU, W., YANG, J., JIANG, Y., ZHANG, H., YANG, Z., WANG, Y., ZHENG, Q. 2011. Randomised clinical trial: the effects of perioperative probiotic treatment on barrier function and post-operative infectious complications in colorectal cancer surgery -a double-blind study. Aliment. Pharmacol. Ther. 33, 50-63. http://dx.doi.org/10.1111/j.13652036.2010.04492.x 
MCFARLAND, LV. 2014. Use of probiotics to correct dysbiosis of normal microbiota following disease or disruptive events: a systematic review. BMJ Open. 4, e005047. http://dx.doi.org/10.1136/bmjopen-2014-005047.

MOHAMADZADEH, M., OLSON, S., KALINA, W.V., RUTHEL, G., DEMMIN, G.L., WARFIELD, K.L., BAVARI, S., KLAENHAMMER, T.R. 2005. Lactobacilli activate human dendritic cells that skew T cells toward T helper 1 polarization. Proc. Natl. Acad. Sci. 102, 2880-2885. http://dx.doi.org/10.1073/pnas.0500098102.

LEBEER, S., CLAES, I., TYTGAT, H.L., VERHOEVEN, T.L., MARIEN E., VON OSSOWSKI, I., REUNANEN, J., PALVA, A., VOS, W.M., KEERSMAECKER, S.C., VANDERLEYDEN, J. 2012. Functiona analysis of Lactobacillus rhamnosus GG pili in relation to adhesion and immunomodulatory interactions with intestinal epithelial cells. Appl. Environ. Microbiol. 78, 185-193. http://dx.doi.org/10.1128/aem.06192-11.

LEBEER, S., VANDERLEYDEN, J., DE KEERSMAECKER, C.J. 2010. Host interactions of probiotic bacterial surface molecules: comparison with commensals and pathogens. Nat. Rev. Microbiol. 8, 171-184. http://dx.doi.org/10.1038/nrmicro2297.

LEE, J.W., SHIN, J.G., KIM, E.H., KANG, H.E., YIM, I.B., KIM, J.Y., JOO, H.G., WOO, H.J. 2004. Immunomodulatory and antitumor effects in vivo by the cytoplasmic fraction of Lactobacillus casei and Bifidobacterium longum. J. Vet. Sci. 5, 41-48.

LIN, C.S., CHANG, C.J., LU, C.C., MARTEL, J., OJCIUS, D.M., KO, Y.F., YOUNG, J.D., LAI, HC. 2014. Impact of the gut microbiota, prebiotics, and probiotics on human health and disease. Biomed. J. doi: 10.4103/2319 4170.138314 .

LIONG, M.T. 2011. Probiotics: Biology, Genetics and Health Aspects. Microbiology Monographs. Heidelberg, Springer.

MORA, J.R., IWATA, M., EKSTEEN, B., SONG, S.Y., JUNT, T., SENMAN, B., OTIPOBY, K.L., YOKOTA, A., TAKEUCHI, H., RICCIARDICASTAGNOLI, P., RAJEWSKY, K., ADAMS, D.H., VON ANDRIAN, U.H 2006. Generation of gut-homing IgA-secreting B cells by intestinal dendritic cells. Sci. 314, 1157-1160. http://dx.doi.org/10.1126/science.1132742.

NIELSEN, D.S., CHO, G.S., HANAK, A., HUCH, M., FRANZ, C.M., ARNEBORG, N. 2010. The effect of bacteriocin-producing Lactobacillus plantarum strains on the intracellular $\mathrm{pH}$ of sessile and planktonic Listeria monocytogenes single cells. Int. J. Food Microbiol. 141, S53-S59. http://dx.doi.org/10.1016/j.ijfoodmicro.2010.03.040.

NG, S.C., HART, A.L., KAMM, M.A., STAGG, A.J., KNIGHT, S.C. 2009 Mechanisms of action of probiotics: recent advances. Inflamm. Bowel Dis. 15, 300-310. http://dx.doi.org/10.1002/ibd.20602.

MARTIN, E. P., WANG, Y., SPRENGER, N., YAP, I. K., LUNDSTEDT, T., LEK, P., REZZI, S., RAMADAN, Z., VAN BLADEREN, P., FAY, L. B., KOCHHAR, S., LINDON J.C., HOLMES E., NICHOLSON, J.K. 2008 Probiotic modulation of symbiotic gut microbial-host metabolic interactions in humanized microbiome mouse model. Mol. Syst. Biol. 4, 157 http://dx.doi.org/10.1038/msb4100190.

OHLAND, C.L., MACNAUGHTON, W.K. 2010. Probiotic bacteria and intestinal epithelial barrier function. Am. J. Physiol. Gastrointest. Liver Physiol. 298, G807-819. http://dx.doi.org/10.1152/aipgi.00243.2009.

O'MAHONY, L., FEENEY, M., O'NALLORAN, S., MURPHY, L., KIELY, B., FITZGIBBON, J., LEE, G., O'SHEA, E.F., COTTER, P.D., STANTON, C., ROSS, R.P., HILL, C. 2012. Production of bioactive substances by intestinal bacteria as a basis for explaining probiotic mechanisms: bacteriocins and conjugated linoleic acid. Int. J. Food Microbiol. 152, 189-205. http://dx.doi.org/10.1016/j.ijfoodmicro.2011.05.025.

O'SULLIVAN, G., SHANAHAN, F., COLLINS, J.K. 2001. Probiotic impact on microbial flora, inflammation and tumor development in IL-10 knockout mice. Aliment. Pharmacol. Ther. 15, 1219-1225. http://dx.doi.org/10.1046/j.13652036.2001.01027.x.

PATURI, G., PHILLIPS, M., JONES, M,. KAILASAPATHY, K. 2007. Immune enhancing effects of Lactobacillus acidophilus LAFTI L10 and Lactobacillus paracasei LAFTI L26 in mice. Int. J. Food Microbiol. 115, 115-118. http://dx.doi.org/10.1016/j.ijfoodmicro.2006.10.007.

POSSEMIERS, S., MARZORATI, M., VERSTRAETE, W. WIELE, T.V. 2010 Bacteria and chocolate: A successful combination for probiotic delivery. Int. $J$. Food Microbiol. 141,

http://dx.doi.org/10.1016/j.ijfoodmicro.2010.03.008.

PRINCE, T., MCBAIN, A.J., O'NEILL, C.A. 2012. Lactobacillus reuter protects epidermal keratinocytes from Staphylococcus aureus-induced cell death by competitive exclusion. Appl. Environ. Microbiol. 78, 5119-26. http://dx.doi.org/10.1128/aem.00595-12.

RAD, A.H., MEHRABANY, E.V., ALIPOOR, B., MEHRABANY, L.V. 2014 The comparison of food and supplement as probiotics delivery vehicles. Crit. Rev. Food Sci. Nutr. http://dx.doi.org/10.1080/10408398.2012.733894.

RAJPUT, I.R., HUSSAIN, A., LI, Y.L., ZHANG, X., XU, X., LONG M.Y., YOU, D.Y., LI, W.F. 2014. Saccharomyces boulardii and Bacillus subtilis B10 modulate TLRs mediated signaling to induce immunity by chicken BMDCs. J. Cell Biochem. 115,189-98. http://dx.doi.org/10.1002/jcb.24650.

RANADHEERA, R.D.S.C., BAINES, S.K. ADAMS, M.C. 2010. Importance of food in probiotic efficacy. Food Res. Int. 43, 1-7. http://dx.doi.org/10.1016/j.foodres.2009.09.009.

RAUTAVA, S., COLLADO, M.C., SALMINEN, S., ISOLAURI, E. 2012 Probiotics modulate host-microbe interaction in the placenta and fetal gut: a randomized, double-blind, placebo-controlled trial. Neonatol. 102, 178-184. http://dx.doi.org/10.1159/000339182

RAZDAN, K., PARIHAR, J., BAJAJ B.K. 2012. Isolation and characterization of a lipolytic and phytase producing probiotic for potential application in poultry feed. Online J. Anim. Feed Res. 2, 369-377.

RUPA, P., MINE, Y. 2012. Recent advances in the role of probiotics in human inflammation and gut health. J. Agric. Food Chem. 60, 8249-56. http://dx.doi.org/10.1021/jf301903t.

SANDERS, M.E., LENOIR-WIJNKOOP, I., SALMINEN, S., MERENSTEIN, D.J., GIBSON, G.R., PETSCHOW, B.W., NIEUWDORP, M., TANCREDI, D.J., CIFELLI, C.J., JACQUES, P., POT, B. 2014. Probiotics and prebiotics: prospects for public health and nutritional recommendations. Ann. N Y Acad. Sci. 1309:19-29. http://dx.doi.org/10.1111/nyas.12377

SAWADA, N., MURATA, M., KIKUCHI, K., OSANAI, M., TOBIOKA, H., KOJIMA, T., CHIBA, H. 2003. Tight junctions and human diseases. Med. Electron. Microsc. 36, 147-56.

SCHREZENMEIR, J., DE VRESE, M. Probiotics, prebiotics and synbioticsapproaching a definition. Am. J Clin. Nutr. 2001; 73:361-364.

SCHIFFRIN, E.J., BLUM, S. 2001. Food processing: probiotic microorganisms for beneficial foods. Curr. Opin. Biotechnol. 12, 499-502 http://dx.doi.org/10.1016/s0958-1669(00)00253-6.

SHARMA, R., KAPILA, R., DASS, G., KAPILA, S. 2014. Improvement in Th1/Th2 immune homeostasis, antioxidative status and resistance to pathogenic $E$. coli on consumption of probiotic Lactobacillus rhamnosus fermented milk in aging mice. Age 36, 9686 http://dx.doi.org/10.1007/s11357-014-9686-4.

SMUG, L.N., SALMINEN, S., SANDERS, M.E., EBNER, S. 2014. Yoghurt and probiotic bacteria in dietary guidelines of the member states of the European Union. Benef. Microbes. 5, 61-66. http://dx.doi.org/10.3920/bm2013.0050.

SUN, J., LE, G.W., SHI, Y.H., SU, G.W. 2007. Factors involved in binding of Lactobacillus plantarum Lp6 to rat small intestinal mucus. Lett. Appl. Microbiol. 44, 79-85. http://dx.doi.org/10.1111/j.1472-765x.2006.02031.x.

SUN, J., SHI, Y.H., LE, G.W., MA, X.Y. 2005. Distinct immune response induced by peptidoglycan derived from Lactobacillus sp. World J. Gastroenterol. $11,6330-6337$

TIMMERMANA, H.M., KONINGB, C.J.M., MULDERC, L., ROMBOUTSD, F.M., BEYNENA, A.C. 2004. Monostrain, multistrain and multispecies probiotics-A comparison of functionality and efficacy. Int. J. Food Microbiol. 96 219-233. http://dx.doi.org/10.1016/j.ijfoodmicro.2004.05.012.

TOOLEY, K., HOWARTH, G., LYMN, K., LAWRENCE, A., BUTLER, R 2006. Oral ingestion of Streptococcus thermophilus diminishes severity of smal intestinal mucositis in methotrexate treated rats. Cancer Biol. Ther. 5, 593-600 http://dx.doi.org/10.4161/cbt.5.6.2659.

TSAI, Y.T., CHENG, P.C., PAN, T.M 2012.The immunomodulatory effects of lactic acid bacteria for improving immun e functions and benefits. Appl. Microbiol. Biotechnol. 96, 853-862. http://dx.doi.org/10.1007/s00253-012-4407-3.

VAN BAARLEN, P., TROOST, F., VANDER MEER, C., HOOIVELD, G. BOEKSCHOTEN, M., BRUMMER, R.J.M., KLEEREBEZEM, M. 2011 Human mucosal in vivo transcriptome responses to three lactobacilli indicate how probiotics may modulate human cellular pathways. Proc. Natl. Acad. Sci. 108, 4562-4569. http://dx.doi.org/10.1073/pnas.1000079107.

VAN GUELPEN, B., HULTDIN, J., JOHANSSON, I., HALLMANS, G., STENLING, R., RIBOLI, E., WINKVIST, A., PALMQVIST, R. 2006. Low folate levels may protect against colorectal cancer. Gut 55, 1461-1466. http://dx.doi.org/10.1136/gut.2005.085480.

VAN HEMERT, S., VERWER, J., SCHÜTZ, B. 2013. Clinical Studies Evaluating Effects of Probiotics on Parameters of Intestinal Barrier Function Adv. Microbiol. 3, 212-221. http://dx.doi.org/10.4236/aim.2013.32032.

VAN TASSELL, M.L., MILLER M.J. 2011. Lactobacillus adhesion to mucus Nutrients 3, 613-636. http://dx.doi.org/10.3390/nu3050613

VILA, B., ESTEVE-GARCIA, E., BRUFAU, J. 2010. Probiotic microorganisms: 100 years of innovation and efficacy; modes of action. World's Poult. Sci. J. 65 , 369-380. http://dx.doi.org/10.1017/s0043933910000474.

WANG, H., GONG, J., WANG, W., LONG, Y., FU, X., FU, Y., QIAN, W., HOU, X. 2014. Are There Any Different Effects of Bifidobacterium, Lactobacillus and Streptococcus on Intestinal Sensation, Barrier Function and Intestinal Immunity in PI-IBS Mouse Model? PLoS ONE 9, e90153. http://dx.doi.org/10.1371/journal.pone.0090153.

Wilson, K.H., Perini, F. 1988. Role of competition for nutrients in suppression of Clostridium difficile by the colonic microflora. Infect. Immun. 56, 2610-2614.

WOO, J., AHN, J. 2013. Probiotic-mediated competition, exclusion and displacement in biofilm formation by food-borne pathogens. Lett. Appl. Microbiol. 56, 307-13. http://dx.doi.org/10.1111/lam.12051.

YAN, F., CAO, H., COVER,T.L., WASHINGTON, M.K., SHI, Y., LIU, L., CHATURVEDI, R., PEEK, R.M. JR., WILSON, K.T., POLK, D.B. 2011. 
Colon-specific delivery of a probiotic-derived soluble protein ameliorates intestinal inflammation in mice through an EGFR-dependent mechanism. J. Clin.

Invest. 121, 2242-2253. http://dx.doi.org/10.1172/jci44031.

YAN, F., POLK, D.B. 2002. Probiotic Bacterium Prevents Cytokine-induced Apoptosis in Intestinal Epithelial Cells. The J. Biol. Chem. 277, 50959-50965. http://dx.doi.org/10.1074/jbc.m207050200. 